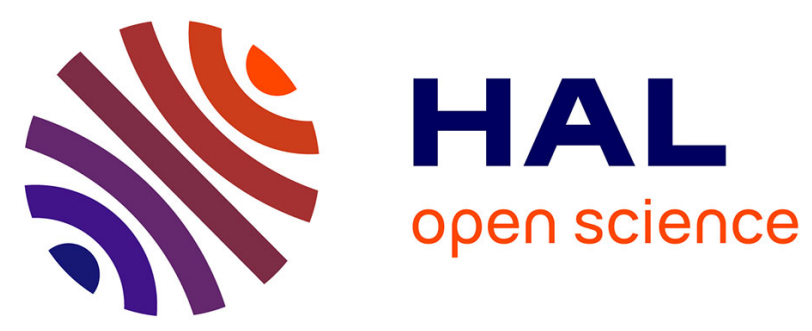

\title{
Carbon isotopes and iodine concentrations in a Mississippi River delta core recording land use, sediment transport, and dam building in the river's drainage basin
}

\author{
Peter H. Santschi, Sarah D. Oktay, Luis Cifuentes
}

\section{- To cite this version:}

Peter H. Santschi, Sarah D. Oktay, Luis Cifuentes. Carbon isotopes and iodine concentrations in a Mississippi River delta core recording land use, sediment transport, and dam building in the river's drainage basin. Marine Environmental Research, 2007, 63 (3), pp.278. 10.1016/j.marenvres.2006.11.002 . hal-00562964

\section{HAL Id: hal-00562964 \\ https://hal.science/hal-00562964}

Submitted on 4 Feb 2011

HAL is a multi-disciplinary open access archive for the deposit and dissemination of scientific research documents, whether they are published or not. The documents may come from teaching and research institutions in France or abroad, or from public or private research centers.
L'archive ouverte pluridisciplinaire HAL, est destinée au dépôt et à la diffusion de documents scientifiques de niveau recherche, publiés ou non, émanant des établissements d'enseignement et de recherche français ou étrangers, des laboratoires publics ou privés. 


\section{Accepted Manuscript}

Carbon isotopes and iodine concentrations in a Mississippi River delta core re $\square$ cording land use, sediment transport, and dam building in the river's drainage basin

Peter H. Santschi, Sarah D. Oktay, Luis Cifuentes

PII:

S0141-1136(06)00207-8

DOI:

10.1016/j.marenvres.2006.11.002

Reference:

MERE 3078

To appear in:

Marine Environmental Research

Received Date:

3 January 2006

Revised Date:

13 November 2006

Accepted Date:

13 November 2006

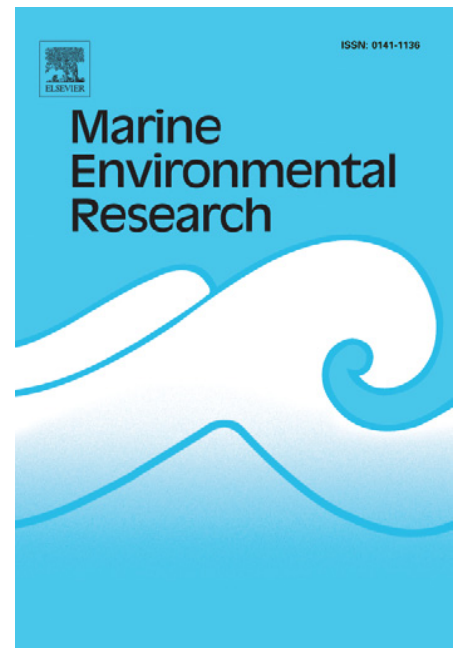

Please cite this article as: Santschi, P.H., Oktay, S.D., Cifuentes, L., Carbon isotopes and iodine concentrations in a Mississippi River delta core recording land use, sediment transport, and dam building in the river's drainage basin, Marine Environmental Research (2006), doi: 10.1016/j.marenvres.2006.11.002

This is a PDF file of an unedited manuscript that has been accepted for publication. As a service to our customers we are providing this early version of the manuscript. The manuscript will undergo copyediting, typesetting, and review of the resulting proof before it is published in its final form. Please note that during the production process errors may be discovered which could affect the content, and all legal disclaimers that apply to the journal pertain. 
Carbon isotopes and iodine concentrations in a Mississippi River delta core recording land use, sediment transport, and dam building in the river's drainage basin

Peter H. Santschi ${ }^{1}$, Sarah D. Oktay ${ }^{1,2}$, and Luis Cifuentes ${ }^{3}$

1) Laboratory for Oceanographic and Environmental Research (LOER), Dept. of Marine Sciences and Oceanography, Texas A\&M University at Galveston, 5007 Ave U, Galveston, TX 77551 (santschi@tamug.edu).

2) University of Massachusetts - Boston, Nantucket Field Station, Grace Grossman Environmental Center, 180 Polpis Rd, Nantucket, MA 02554 (sarah.oktay@umb.edu).

3) Department of Oceanography, Texas A\&M University, College Station, TX 77843 (lcifuentes@ocean.tamu.edu).

Marine Environmental Research

submitted: January 2006

revised: October 2006

\section{Keywords}

Mississippi River delta; organic carbon; sediment transport; land use, radiocarbon; C-13; iodine; salt marsh 


\begin{abstract}
Sedimentary material from coastal and nearshore areas in the Mississippi Delta region are comprised of different organic carbon sources with diverse ages that require isotopic and elemental records for resolving the various sources of plant residues. Carbon isotopic $\left({ }^{13} \mathrm{C},{ }^{14} \mathrm{C}\right)$ values were used to differentiate contributions from plants using the $\mathrm{C} 3, \mathrm{C} 4$, and/or CAM (crassulacean acid metabolism) carbon fixation pathways., and iodine concentrations indicated that wetland plant residues are a significant source of organic carbon in a sediment core from the Mississippi River Delta region collected at a $60 \mathrm{~m}$ water depth. This sediment core had been extensively described in Oktay et al. (2000), and significantly, includes unique features that had not previously been seen in the marine environment. These special features include a plutonium isotopic close-in fallout record that indicates a purely terrestrial source for these sediment particles and the elements associated with it, and a distinct iodine isotopic peak (as well as peaks for plutonium and cesium isotopes) that indicate little bioturbation in this core. Our carbon isotopic and iodine data can thus be compared to published records of changes in drainage basin land use, river hydrology, and hydrodynamic sorting of suspended particles to elucidate if these changes are reflected in nearshore sediments. This comparison suggests a significant contribution for organic carbon (OC) from C4 plants to these sediments during the 1950's to early 1960's. Relative older carbon isotopes, and episodically high iodine concentrations (up to $34 \mathrm{ppm}$ ) were observed during this time period that 1) indicate sediment deposition that is coincident with the times of major hydrological changes induced from dam and levee building in both the upper and lower reaches of the Mississippi River drainage basin, and 2) suggest episodic organic carbon deposition from wetland plant residues.
\end{abstract}




\section{Introduction}

The Mississippi River watershed is the largest of the contiguous United States, draining approximately $40 \%$ of its surface area. The Mississippi River is also by far the largest source of sediment and organic matter to the Gulf of Mexico. In its delta region, the potential exists for reconstructing the history of organic matter sources eroded from a large part of the U.S. drainage basins through analysis of particulate organic carbon, POC, in radioisotopically-dated sediment cores. There have been relatively few attempts to interpret organic carbon isotopic records in terms of its sources and in a historical context (e.g., Eadie et al., 1994). Since suspended sediment loads change in response to variations in hydrological conditions along the river, and suspended sediments reaching the delta and shelf regions of the Gulf of Mexico are sorted hydrodynamically (Bianchi et al., 2002), comparing organic carbon source datum in Mississippi Delta area sediment cores with the drainage basin historical record will have to take into account both changes in hydrological conditions as well as hydrodynamic regimes.

Of particular interest are changes in hydrological conditions such as the construction of dams and levees that were installed to reduce flooding or accommodate increases in traffic on the river. As part of the New Deal, Roosevelt backed the construction of locks and dams in order to improve trade and transportation and provide work for Americans struggling to survive after the Depression. For instance, the Fort Peck dam was constructed on the Upper Missouri in Montana between 1933 and 1940, and at the time it was built was the $5^{\text {th }}$ largest dam in the world and is still one of the world's largest earth-filled dams. In 1953, flood control dam construction began again on the Missouri River and all dam construction was completed by 1967. The Missouri River which joins the upper Mississippi near St Louis has always been the primary contributor of sedimentary material to the Mississippi, but this total contribution was reduced by $70 \%$ after the construction of these dams (Keown et al., 1986). The average annual sediment load has decreased three-fold as measured at a station in St, Louis Missouri, with a reduction from the 1953 value of $3.19 \times 10^{8}$ tons per year to $1.1 \times 10^{8}$ tons per year in 1967 . Dissolved silicate loads decreased as well due to removal behind newly constructed dams (Carey et al., 1999). This large decrease in sediments from damming the western tributaries (Missouri and Arkansas rivers) was counterbalanced by a significant increase in sediment loads from the Ohio River resulting from deforestation and rowcrop farming (Keown, 1986).

As a consequence of the reduced loads from the Missouri River, the sediment load determined at Tarbert Landing along the main stem of the Mississippi River flowing into the Gulf of Mexico decreased from 3.0x $10^{8}$ tons/yr from 1950-1962 to $1.6 \times 10^{8}$ tons/yr for the period 1970-1978. Concurrent to the changes in flood control dams for the Mississippi River in the upper drainage basin, Old River Control Structures were constructed to regulate the flow to the Atchafalaya River in order to partition the flow between the main stem and the Atchafalaya River and prevent rapid silting of navigation channels in the lower Mississippi River. They were completed and became operational in 1963.

According to Keown et al. (1986), approximately $75 \%$ of the total sediment discharged from the lower Mississippi River was derived from the Missouri River before the 1950's. Recent work has shown that bulk particle organic carbon (POC) derived from the dominant sources of grasslands in the Missouri River watershed has a lignin signature that is typical of non-woody angiosperm sources (Onstad et al., 2000). Erosion of soils of the Mississippi River drainage basin with 
extensive grasslands containing isotopically heavier $\mathrm{C} 4$ plants is a main contributor of POC in the Mississippi River (Goni et al., 1997). Downcore variations of the $\delta^{13} \mathrm{C}$ signature of POC from a site located in the Mississippi River Delta region were previously interpreted as changes between marine productivity and terrestrial organic matter inputs (Eadie et al., 1994). However, these data can be reinterpreted using the data of Goni et al. (1997) by considering the contribution of terrestrial POC from $\mathrm{C} 4$ plants that has increased during the past century. Land use changed in the Mississippi River Basin from the predominantly grassland (C4)-forest settings of the early $19^{\text {th }}$ century to the current intensive use of over one third of the land in the basin for agricultural purposes (Keown et al., 1986).

A mechanism has been proposed by Bianchi et al. (2002) that can explain the observations of POC deposition in riverine and nearshore regions of woody C3 plant derived carbon, and of C4 plant-derived POC further offshore in shelf and slope sediments. These authors suggested hydrodynamic sorting of POC in Mississippi River Delta regions and the shelf waters, primarily as a result of frequent resuspension of sediments in the river bed caused by changes in river discharge. This would cause fine-grained sediments to be winnowed out in the water column and transported downstream, while the larger sediments with woody material associated with it and with higher relative densities would selectively settle out in the lower river and inner shelf sediments.

Changes in erosion river beds near New Orleans have also occurred in the 1960s in response to changes in subsidence and river hydrology (Galler et al., 2003). This has exposed peat deposits with radiocarbon ages of 2000-4000 years, and $\delta^{13} \mathrm{C}$ values of -24.6 to $-25 \%$. Keppler et al. (2004) found that peatlands sequester large amounts of iodine with average concentrations of 5$36 \mathrm{mg} / \mathrm{kg}$, therefore, one could recognize such layers in a sedimentary record by their unusually high iodine concentrations.

There are other organic matter sources with high iodine concentrations, however, such as salt marsh vegetation, which typically have heavy $\delta^{13} \mathrm{C}$ signatures due to $\mathrm{C} 4$ photosynthetic pathways (Hoefs, 1987; Fuge and Johnson, 1986). Thus, the combined use of carbon isotopes and iodine concentrations become promising tools to differentiate peat from salt marsh organic matter sources.

Here, we will compare organic carbon isotopic and iodine records that are imprinted into a previously described Mississippi River Delta sediment core (Oktay et al., 2000). This nearshore (60 $\mathrm{m}$ water depth) sediment core from the Mississippi River delta region is unique in that it has preserved the terrestrial close-in plutonium bomb fallout record that has not been documented in any previously published marine record. Early US bomb tests at the Nevada test site conducted in the early 1950's were low-yield and near-ground, moving large radioactive dust clouds from Nevada across the continental USA, which received fallout with low ${ }^{240} \mathrm{Pu} /{ }^{239} \mathrm{Pu}$ ratios of 0.05 and lower. While marine sediment $\mathrm{Pu}$ isotopic ratios below the sediment surface have only documented global bomb fallout ${ }^{240} \mathrm{Pu} /{ }^{239} \mathrm{Pu}$ ratios of 0.18 , the sedimentary record of $\mathrm{Pu}$ isotopes by Oktay et al. (2000) is, to our knowledge, the only marine record of the terrestrial close-in fallout from the Nevada test site. Thus, the low Pu isotopic ratio deeper in this sediment core is strong evidence that $\mathrm{Pu}$ and associated elements in this sediment core from this Mississippi River delta site are mainly from terrestrial sources, with minimal marine input. Furthermore, the iodine isotopic record from bomb fallout contains a sharp 1963 fallout peak that is preserved in this 
sediment core material, and thus clearly indicates a record with little alteration by benthic bioturbation or iodine diagenesis.

Most importantly, this sediment core allowed us to compare the sedimentary organic carbon and iodine signals with recorded changes in drainage basin land use, river hydrology, and hydrodynamic sorting of suspended particles. Since coastal areas are subject to organic carbon from different sources with different ages, the interpretation of any carbon isotopic record is often a challenging task, and requires additional isotopic and elemental records (e.g., Santschi et al., 2001a). The fallout isotopic records (e.g., ${ }^{239} \mathrm{Pu} /{ }^{240} \mathrm{Pu},{ }^{137} \mathrm{C},{ }^{129} \mathrm{I} /{ }^{127} \mathrm{I}$, and ${ }^{210} \mathrm{~Pb}_{\mathrm{xs}}$ ) that are available from the work of Oktay et al. (2000) thus provide a unique opportunity to investigate the historical record of terrestrial organic matter inputs into the Mississippi River delta region through the additional analyses of organic carbon isotopes $\left({ }^{13} \mathrm{C},{ }^{14} \mathrm{C}\right)$.

\section{Methods and experimental approaches}

\section{Sampling}

Two sediment cores from the Mississippi River Bight were taken during the 1993 Texas A\&M University research cruise 93P13 (aboard the R/V Pelican), approximately $24 \mathrm{~km}$ due west of the mouth of the South West Pass of the Mississippi River (Figure 1). This location was chosen in order to procure sediment cores with predictably high sedimentation rates based on their location within the plume of particulate material that exits the Mississippi River as can be clearly seen in Figure 1. The core location in the Mississippi River Delta region are: core 93P13 \#2 at $28^{\circ} 55.5^{\prime}$ $\mathrm{N}, 89^{\circ} 40.6^{\prime} \mathrm{W}$ in about $60 \mathrm{~m}$ water depth in the vicinity of Southwest Pass, of which the radiochemical results are described in Oktay et al. (2000), and carbon isotopic results described here), and parallel core 93P13 \#1 from the same general site, of which the persistent inorganic and organic pollutants, as well as accompanying radiochemical results are described in Santschi et al. (2001).

\section{Analytical techniques}

Isotopic analyses of $\delta^{13} \mathrm{C}$ and $\Delta^{14} \mathrm{C}$ were conducted on dry sediment core material. Five 500-600 mg sediment aliquots were analyzed for $\Delta^{14} \mathrm{C}$ by the Accelerator Mass Spectrometry (AMS) facility at the Lawrence Livermore National Laboratory (LLNL), with relative standard deviations of $\pm 5-10 \%$ (corresponding to errors in radiocarbon ages of 50-100 years). $\delta^{13} \mathrm{C}$ was measured on $100 \mathrm{mg}$ aliquots of several depths throughout the core via conventional mass spectrometry, according to Cifuentes et al. (1988) and Guo and Santschi (1997). The precision and accuracy of the $\mathrm{d}^{13} \mathrm{C}$ analysis was better than $0.1 \%$, as determined from replicate analyses of standards and samples (Guo et al., 1996); actual 1 standard deviation values are given in Table 1. Organic and inorganic carbon concentrations were obtained using a Perkin Elmer CHN/S analyzer on $0.5 \mathrm{~g}$ sediment aliquots. The relative standard deviation of the particulate organic carbon analysis was $\pm 1 \%$ (relative) as determined from replicate analyses of standards and samples (Guo and Santschi, 1997), which would result in a standard deviation of $0.01 \%$ at $1 \%$ OC. Stable iodine $\left(\mathrm{I}^{127}\right)$ concentrations, previously published in Oktay et al. (2000), were measured via ICP-MS using either a Sciex/Perkin Elmer ELAN 500 or a Hewlett Packard model 4500 instrument, after extraction of iodine from the sediments using an alkali leach and fusion method (Nishizumi et al., 1983). The sediment samples were placed in alumina oxide crucibles 
with a saturated $\mathrm{NaOH}$ solution and dried overnight. Next, concentrated $\mathrm{Na}_{2} \mathrm{O}_{2}$ was added and the mixture is heated in a muffle furnace, first at $300^{\circ} \mathrm{C}$ for 30 minutes and then at $600^{\circ} \mathrm{C}$ for 2 hours. De-ionized water, $1 \mathrm{M} \mathrm{NaHSO}_{3}$ and $50 \% \mathrm{H}_{2} \mathrm{SO}_{4}$ were added to help dissolve the majority of the material. Finally, the sample was centrifuged and the supernatant decanted for iodine processing (Oktay et al., 2000).

Analytical results are shown in Table 1 . As $\delta^{13} \mathrm{C}$ data show only gradual changes, this allowed interpolations for missing data points that were used to compare with $\bullet^{14} \mathrm{C}$ values.

\section{Results and discussion}

The ${ }^{210} \mathrm{~Pb}_{\mathrm{xs}}$ and ${ }^{239,240} \mathrm{Pu}$ and/or ${ }^{240} \mathrm{Pu} /{ }^{239} \mathrm{Pu}$ geochronology of this sediment core makes it possible to determine average sedimentation rates for certain depth intervals, and to assign dates at three specific depths throughout the core: 1993 (surface), 1963 (at $21 \mathrm{~cm}$; denoting the bomb fallout peak) and 1953 (at $59 \mathrm{~cm}$; beginning of significant fallout from atmospheric testing of atomic bombs). Corresponding dates between these event horizons were assigned via linear interpolation using the calculated sedimentation rate for each portion. ${ }^{210} \mathrm{~Pb}_{\mathrm{xs}}$ dating indicates a break in sedimentation rates in the early 1960's, as the sedimentation rate decreased from 2 $\mathrm{cm} / \mathrm{yr}$ before that time to $0.7 \mathrm{~cm} / \mathrm{yr}$ in recent years (Oktay et al., 2000), in accordance with a decrease in sediment supply at the same time.

Radiocarbon and $\delta^{13} \mathrm{C}$ data (Figure 2) from organic carbon (OC) in this delta sediment core that was previously dated using plutonium isotopic ratios and ${ }^{210} \mathrm{~Pb}_{\mathrm{xs}}$ (Oktay et al., 2000) shows not only a minimum (Figure 2a) in $\Delta^{14} \mathrm{C}$ and maximum (Figure $2 \mathrm{~b}$ ) in $\delta^{13} \mathrm{C}$, but also a maximum in total iodine in layers dated as 1957 (Figure 3). Iodine in suspended and sinking sediments is mostly from geochemically modified erosional inputs in response to higher river flow rates (Oktay et al., 2001). $\Delta^{14} \mathrm{C}$ data from shelf environments receiving multiple sources of organic carbon are more difficult to interpret than those from delta regions of large rivers such as the Mississippi River. For example, a changing $\Delta^{14} \mathrm{C}$ signal from bulk POC can be a result of a variable mixing ratio of old riverine and/or shelf organic carbon into a marine organic carbon background source (e.g., Palos Verdes shelf; Santschi et al., 2001a).

While $\delta^{13} \mathrm{C}$ peaks in about 1957 , and $\Delta{ }^{14} \mathrm{C}$ shows a minimum at about the same time, ${ }^{240} \mathrm{Pu} /{ }^{239} \mathrm{Pu}$ ratios are steadily decreasing in sediments older than 1963 , and ${ }^{137} \mathrm{Cs}$ required decay correction to the time of deposition because of transport and drainage basin effects (Oktay et al., 2000). Most important for lack of iodine mobility and lack of bioturbation, ${ }^{129} \mathrm{I}^{127}$ I ratios exactly track the $\mathrm{Pu}$ isotopic ratios (Figure 5 of Oktay et al., 2000), despite multiple sources. This indicates that the ${ }^{129} \mathrm{I},{ }^{239} \mathrm{Pu}$ and ${ }^{240} \mathrm{Pu}$ and other bomb fallout nuclides were from Mississippi River drainage basin soils, deposited from close-in tropospheric fallout originating from the Nevada test sites in the 1950's (Oktay et al., 2000). Therefore sediments and POC in this section of the core are clearly of terrestrial origin.

Thus, the observations of changing sedimentation rate, coupled to the change in carbon isotopic signatures of sedimentary organic carbon can be interpreted relative to decreases in sediment supply to the delta caused by anthropogenic modification of the river flow regime, as well as changes in organic carbon sources. 
Interestingly, core 93P13\#1, taken from a nearby site (Santschi et al., 2001b), showed similar sedimentation rates over the past $50-100$ years based on ${ }^{210} \mathrm{~Pb}_{\mathrm{xs}}$ and ${ }^{239,240} \mathrm{Pu}$ peaks, i.e., 0.7 $\mathrm{cm} / \mathrm{yr}$, but did not show decreasing ${ }^{240} \mathrm{Pu} /{ }^{239} \mathrm{Pu}$ ratios below the peak. This suggests that the depositional environment near the site our core (93P13 \#2) was taken was uneven, possibly with bottom flows of river sediment fingering out from the delta region. Inventories of particlereactive ${ }^{239,240} \mathrm{Pu}$ in both cores from this site were enhanced over those expected from atmospheric deposition, which is to be expected for a river delta region. While $\mathrm{Pu}$ isotope inventories in sediments off the Mississippi River Delta are elevated and decrease with increasing water depth (Yeager et al., 2004), this elevated Pu inventory in our core, together with the unique signature of lower ${ }^{240} \mathrm{Pu} /{ }^{239} \mathrm{Pu}$ ratios in subsurface sediments, also agrees with our contention of significant inputs of terrestrial material to the area our sediment core was taken.

Iodine concentrations in our core peak near a depth of $40 \mathrm{~cm}$ (dated to around 1957), and periodically below, with significant offsets of these few data points from the trend line of iodine vs. OC concentration (Figure 4). While the trend line shows molar I/C ratios of about $5 \times 10^{-5}$, the few high points with higher iodine concentrations have molar I/C ratios of about $20 \times 10^{-5}$. No I/C data is available from Mississippi River wetlands. However, both ratios appear somewhat higher than reported I/C ratios in peat bogs from Southern Chile (e.g., 1x10 ${ }^{-5}$; Keppler et al., 2004).

This suggests episodic deposition of organic material from a high iodine content, relatively low carbon (e.g. in comparison to algae) source such as peat or marsh plant residues. Organic carbon from such a source, while old, indicates C4 or CAM (crassulacean acid metabolism) origin, as $\delta^{13} \mathrm{C}$ values for this section of the core are relatively heavy $(-21.2 \%$ ), rather than -24 to $-30 \%$ o for the isotopically lighter C3 plants. Furthermore, in the $1956-1993$ data set, ${ }^{14} \mathrm{C}$-age and (interpolated) $\delta^{13} \mathrm{C}$ linearly and significantly correlate (Figure 5, Table 1), suggesting a mixing behavior of at least two distinct carbon sources. While a correlation between ${ }^{14} \mathrm{C}-$ ages and $\delta^{13} \mathrm{C}$ values had been described previously by Gordon and Goni (2003) for nearshore sediments near the Atchafalaya River, albeit with significantly more depleted $\delta^{13} \mathrm{C}$ values ranging from -21 to $27 \%$, characteristic for a large part of the shelf, their range of $\delta^{13} \mathrm{C}$ values is much larger (i.e., 21 to $-27 \%$ ), and their linear correlation (i.e., slope and intercept) is significantly different. Nonetheless, the points in our correlation still fall within the range of values Gordon and Goni (2003) observed.

It might be possible that peat residues dated by ${ }^{14} \mathrm{C}$ to be several thousand years old, exhibiting isotopically depleted $\delta^{13} \mathrm{C}$ signatures $(\sim-25 \%$ ) that had been observed in eroding river beds near New Orleans (Galler et al., 2003) could be the source material. However, because $\delta^{13} \mathrm{C}$ values in our core peak at $-21.2 \%$ and not $-25 \%$, this possibility can be ruled out. Since $\delta^{13} \mathrm{C}$ values of $21.2 \%$ are coincident with higher iodine values, this suggests that our ${ }^{13} \mathrm{C}$ record indicates episodic deposition of more ${ }^{13} \mathrm{C}$ - and iodine-enriched wetland deposits rather than peat residues from old river beds deposited during the 1950's. Wetland plants and their residues are known to contain more isotopically heavy carbon (Hoefs, 1987) that are also enriched in iodine (Fuge and Johnson, 1986). Thus, our sedimentary record suggests that eroded organic carbon from wetlands has episodically been eroded and deposited into these delta sediments during those particular times. 
While Goni et al. (1998) considered the possibility of marsh-derived organic matter as a source of the terrigenous organic matter they observed in Gulf of Mexico sediments, they dismissed this possibility for a number of reasons. They argued that the subsidence of the deltaic plain and surrounding lands should make them a sink and not a source of sediments, and they expected that marsh sediments should be younger in ${ }^{14} \mathrm{C}$-age than the old sediments they observed on the shelf and slope. However, they only considered current conditions, and obviously, hydrological conditions during the 1950's and early 1960's were different. Also, while our data suggests that the OC originates from older wetland deposits that must have periodically been deposited in the delta sediments at $60 \mathrm{~m}$ water depth, these layers with highest iodine concentrations appear to account for only a minor fraction of the sedimentary deposits.

The significant on-shore - off-shore gradient in $\delta^{13} \mathrm{C}$ values on the Louisiana - Mississippi shelf, with $\delta^{13} \mathrm{C}$ values of $-25 \%$ in Mississippi and Atchafalaya Rivers and near-shore sediments, and 22 to $-20 \%$ in outer shelf and slope surface sediments, has been explained by hydrodynamic sorting of POC, with $\mathrm{C} 3$ plant material being heavier and depositing closer to shore, and $\mathrm{C} 4$ plant residues associated with finer-grained particles that are being transported further off-shore (Bianchi et al., 2002). Obviously, this general pattern does not differentiate contributions from different sources of $\mathrm{C} 4$ plant residues, e.g., from grass or marsh lands. Only in combination with iodine signatures, is it possible to distinguish deposits of iodine-enriched wetland-derived POC, which have only small isotopic deviations in $\delta^{13} \mathrm{C}$ values from those of $\mathrm{C} 4$ plants.

\section{Conclusions}

The carbon isotope and iodine data from a Mississippi River delta core correlates not only with changes in land use and decreases in sediment and OC deposition since the early 1960s, but also, shown here for the first time, with episodic organic carbon deposition from older wetland plant residues (which are known to contain high iodine concentrations). This was especially pronounced for sediments deposited in the late 1950's, when sediment deposition rates at this site were higher. The $\delta^{13} \mathrm{C}$ maximum at the same depth also indicates a more significant contribution for OC from C4 plants during the 1950's to early 1960's, coincident with the times of major hydrological changes both in the upper and lower reaches of the Mississippi River drainage basin. Most recently, hurricanes Rita and Katrina allowed a study of their effects on wetlands in Lousiana (Turner et al., 2006), which concluded that hurricanes nourish rather than erode wetlands. Recent sediments in our core contain younger (1560 years) and isotopically lighter OC (-21.96\%o), suggesting a lesser influence of wetland carbon deposits, in accordance with the increased channelization of the Mississippi and Atchafalaya Rivers in recent times.

These findings, even though only documented in one sediment core, are significant as they allow extrapolation to other large rivers that have been dammed and channelized in recent times. However, more work needs to be carried out on inputs from wetlands and the use of ${ }^{239} \mathrm{Pu} /{ }^{240} \mathrm{Pu}$,

$\delta^{13} \mathrm{C}$ and $\mathrm{I} / \mathrm{C}$ ratios in sediment cores as tracers for inputs from different terrestrial environments.

\section{Acknowledgements}

The $\Delta^{14} \mathrm{C}$ results were analyzed by the Accelerator Mass Spectrometry (AMS) facility at the 
Lawrence Livermore National Laboratory (LLNL). This work was supported, in part, by the Coordinating Board of Texas (Advanced Research Program, Grant number 010298-013) and the Texas Institute of Oceanography.

\section{References}

Bianchi, T.S., Mitra, S., \& McKee, B.A. (2002). Sources of terrestrially-derived organic carbon in lower Mississippi River and Louisiana shelf sediments: Implications for differential sedimentation and transport at the coastal margin. Mar. Chem., 77, 211-223.

Carey, A.E., Pennock, J.R., Lehrter, J.C., Lyons, W.B., Schroeder, W.W., \& Bonzongo, J.-C. (1999). The role of the Mississippi River in Gulf of Mexico hypoxia. Prepared for the Fertilizer Institute by the University of Alabama, May 1999.

Cifuentes L. A., Sharp J. H., \& Fogel M. L. (1988). Stable carbon and nitrogen isotope biogeochemistry in the Delaware estuary. Limnol. Oceanogr., 33, 1102-1115.

Corbett, R.D., McKee, B., \& Duncan, D. (2004). An evaluation of mobile mud dynamics in the Mississippi River deltaic region. Mar. Geol., 209, 91-112.

Eadie, B.J., McKee, B.A., Lansing, M.B., Robbins, J.A., Metz, S., \& Trefry, J.H. (1994). Records of nutrient-enhanced coastal ocean productivity in sediments from the Louisiana continental shelf. Estuaries, 17(4), 754-765.

Fuge, R., \& Johnson, C.C. (1986). The geochemistry of iodine - a review. Environ. Geochem. Health, 8, 31-54.

Galler, J.J., Bianchi, T.S., Alison, M.A., Wysocki, L.A., \& Campanella, R. (2003). Biogeochemical implications of levee confinement in the lowermost Mississippi River. EOS 84(44)., November 4, 2003, 469-484.

Goni, M.A., Ruttenberg, K.C., \& Eglinton, T.I. (1997). Sources and contributions of terrigenous organic carbon to surface sediments in the Gulf of Mexico. Nature, 389, 275-278.

Goni, M.A., Ruttenberg, K.C., \& Eglinton, T.I. (1998). A reassessment of the sources and importance of land-derived organic matter in surface sediments from the Gulf of Mexico. Geochim. Cosmochim. Acta, 62(18), 3055-3075.

Gordon, E.S., and Goni, M.A. 2003. Sources and distribution of terrigenous organic matter delivered by the Atchafalaya River to sediments in the northern Gulf of Mexico. Geochim. Cosmochim. Acta, 67(13), 2359-2375.

Guo, L., and Santschi, P.H. 1997. Isotopic and elemental characterization of colloidal organic matter from the Chesapeake Bay and Galveston Bay. Marine Chemistry, 59, 1-15.

Guo, L., P.H. Santschi, L.A. Cifuentes, S. Trumbore, and J. Southon. 1996. Cycling of dissolved organic matter in the Middle Atlantic Bight as revealed by carbon isotopic $\left({ }^{13} \mathrm{C},{ }^{14} \mathrm{C}\right)$ signatures. Limnol. Oceanogr., 41, 1242-1252.

Nishiizumi K., Elmore D., Honda M., Arnold J. R., and Gove H. E. (1983) Measurements of ${ }^{129}$ I in meteorites and lunar rock samples by tandem accelerator mass spectrometry. Nature $\mathbf{3 0 5}$, 611-612.

Hoefs, J. 1987. Stable Isotope Geochemistry, third edition, Springer-Verlag, Berlin, pp. 241.

Keown, M.P., Dardeau, E.A., Jr., \& Causey, E.M. (1986). Historic trends in the sediment flow regime of the Mississippi River. Water Resour. Res., 22(11), 1555-1564.

Keppler, F., Biester, H., Putschw, A., Silk, P.J., Schöler, H.F., \& Müller, G. (2004). Organoiodine formation during humification in peatlands. Environ. Chem. Lett. 1, 219-223.

Oktay, S.D. (1999). ${ }^{129} \mathrm{I}$ Cycling in Terrestrial and Coastal Marine Environments. Ph.D. dissertation, Texas A\&M University, College Station, TX. 
Oktay, S.D., Santschi, P.H., Moran, J.E., \& Sharma, P. (2001). ${ }^{129}$ I and ${ }^{127}$ I transport in the Mississippi River. Environ. Sci. Technol., 35, 4470-4476.

Oktay, S.D., Santschi, P.H., Moran, J.E., \& Sharma, P. (2000). The ${ }^{129}$ Iodine Bomb Pulse Recorded in Mississippi River Delta Sediments: Results from Isotopes of I, $\mathrm{Pu}, \mathrm{Cs}, \mathrm{Pb}$, and $\mathrm{C}$. Geochim. Cosmochim. Acta, 64 (6), 989-996.

Onstad, G.D., Canfield, D.E., Quay, P.D., \& Hedges, J.I. (2000). Sources of particulate organic matter in rivers from the continental USA: lignin phenol and stable carbon isotope compositions. Geochim. Cosmochim. Acta, 64, 3539-3546.

Ruttenberg, K.C., \& Goni, M.A. (1998). Phosphorus distribution, C:N:P ratios, and $\delta^{13} \mathrm{C}$ in arctic, temperate and tropical coastal sediments: Tools for characterizing bulk sedimentary organic matter. Mar. Geol., 139, 123-145.

Santschi, P.H., Guo, L., Asbill, S., Allison, M., Kepple, B., \& Wen, L.-S. (2001a). Accumulation rates and sources of sediments and organic carbon on the Palos Verdes shelf based on multiple radioisotopic tracers $\left({ }^{137} \mathrm{Cs},{ }^{239,240} \mathrm{Pu},{ }^{210} \mathrm{~Pb},{ }^{234} \mathrm{Th},{ }^{238} \mathrm{U}\right.$ and $\left.{ }^{14} \mathrm{C}\right)$. Mar. Chem., 73(2), 125-152.

Santschi, P.H., Presley, B.J., Wade, T.L., Garcia-Romero, B., \& Baskaran, M. (2001b). Historical contamination of PAHs, PCBs, DDTs, and heavy metals in Mississippi River Delta, Galveston Bay and Tampa Bay sediment cores. Mar. Environ. Res., 52(1), 51-79.

Turner, R.E., Baustian, J.J., Swenson, E.M., and Spicer, J.S. 2006. Wetland sedimentation from hurricanes Katrina and Rita. Science, 314, 449-452.

Yeager, K.M., Santschi, P.H., \& Rowe. G.T. (2004). Sediment accumulation and radionuclide inventories $\left({ }^{239,240} \mathrm{Pu},{ }^{210} \mathrm{~Pb}\right.$ and $\left.{ }^{234} \mathrm{Th}\right)$ in the northern Gulf of Mexico, as influenced by organic matter and macrofaunal density. Mar. Chem., 91, 1-14. 
Table 1. Carbon isotopic results from core 93P13 \#2, along with \% OC and iodine data from Oktay et al. (2000). -: not determined; *: interpolated.

\begin{tabular}{|c|c|c|c|c|c|c|}
\hline Depth & $\begin{array}{c}\text { Year of } \\
\text { deposition }\end{array}$ & $\begin{array}{c}\mathrm{OC} \\
( \pm 0.01) \\
(\%)\end{array}$ & $(\% o)$ & $\begin{array}{l}{ }^{14} \mathrm{C} \\
\text { age } \\
\text { (years) }\end{array}$ & $\delta^{13} \mathrm{C}$ & Iodine \\
\hline $\begin{array}{c}0.5 \\
( \pm 0.5)\end{array}$ & 1993 & - & - & - & $\begin{array}{c}-21.96 \\
( \pm 0.004)\end{array}$ & - \\
\hline $\begin{array}{c}1.5 \\
( \pm 0.5)\end{array}$ & & 1.20 & $\begin{array}{l}-177 \\
( \pm 5)\end{array}$ & $\begin{array}{l}1560 \\
( \pm 50)\end{array}$ & $\begin{array}{l}-21.81 \\
( \pm 0.1)^{*}\end{array}$ & - \\
\hline $\begin{array}{c}2.5 \\
( \pm 0.5)\end{array}$ & & 1.07 & - & - & $\begin{array}{l}-21.67 \\
( \pm 0.01)\end{array}$ & $\begin{array}{c}11.5 \\
( \pm 0.5)\end{array}$ \\
\hline $\begin{array}{c}3.5 \\
( \pm 0.5)\end{array}$ & 1987 & 1.11 & - & - & - & $\begin{array}{c}11.6 \\
( \pm 0.5)\end{array}$ \\
\hline $\begin{array}{c}4.5 \\
( \pm 0.5)\end{array}$ & 1986 & - & - & - & $\begin{array}{l}-21.70 \\
( \pm 0.01)\end{array}$ & \\
\hline $\begin{array}{c}5.5 \\
( \pm 0.5)\end{array}$ & 1985 & 1.31 & - & - & & - \\
\hline $\begin{array}{c}6.5 \\
( \pm 0.5)\end{array}$ & 1984 & - & - & - & $\begin{array}{l}-21.72 \\
( \pm 0.01)\end{array}$ & - \\
\hline $\begin{array}{c}7.5 \\
( \pm 0.5)\end{array}$ & & 1.22 & - & - & - & $\begin{array}{c}14.5 \\
( \pm 1.0)\end{array}$ \\
\hline $\begin{array}{c}8.5 \\
( \pm 0.5)\end{array}$ & 1980 & - & & - & $\begin{array}{l}-21.76 \\
( \pm 0.02)\end{array}$ & - \\
\hline $\begin{array}{c}9.5 \\
( \pm 0.5)\end{array}$ & & 1.34 & & - & - & - \\
\hline $\begin{array}{c}11 \\
( \pm 1.0)\end{array}$ & 1977 & 1.41 & - & - & $\begin{array}{l}-21.94 \\
( \pm 0.01)\end{array}$ & - \\
\hline $\begin{array}{c}13 \\
( \pm 1.0)\end{array}$ & & 1.41 & - & - & - & - \\
\hline $\begin{array}{c}15 \\
( \pm 1.0)\end{array}$ & & $1.40^{*}$ & - & - & $\begin{array}{l}-21.65 \\
( \pm 0.02)\end{array}$ & $\begin{array}{c}11 \\
( \pm 1.0)\end{array}$ \\
\hline $\begin{array}{c}17 \\
( \pm 1.0)\end{array}$ & & - & - & - & - & - \\
\hline $\begin{array}{c}19 \\
( \pm 1.0)\end{array}$ & 1964 & 0.95 & - & - & $\begin{array}{c}-21.54 \\
( \pm 0.02)\end{array}$ & $\begin{array}{c}5.7 \\
( \pm 0.3)\end{array}$ \\
\hline $\begin{array}{c}21 \\
( \pm 1.0)\end{array}$ & 1963 & - & $\begin{array}{l}-245 \\
( \pm 7)\end{array}$ & $\begin{array}{l}2260 \\
( \pm 70)\end{array}$ & $\begin{array}{c}-21.52 \\
( \pm 0.03)^{*}\end{array}$ & - \\
\hline $\begin{array}{c}23 \\
( \pm 1.0)\end{array}$ & 1962 & - & - & - & $\begin{array}{l}-21.49 \\
( \pm 0.02)\end{array}$ & - \\
\hline $\begin{array}{c}25 \\
( \pm 1.0)\end{array}$ & 1961 & 0.94 & - & - & - & $\begin{array}{c}7.1 \\
( \pm 1.2)\end{array}$ \\
\hline $\begin{array}{c}27 \\
( \pm 1.0)\end{array}$ & & - & - & - & $\begin{array}{l}-21.55 \\
( \pm 0.07)\end{array}$ & - \\
\hline
\end{tabular}




\section{ACCEPTED MANUSCRIPT}

\begin{tabular}{|c|c|c|c|c|c|c|}
\hline $\begin{array}{c}29 \\
( \pm 1.0)\end{array}$ & 1960 & & - & - & - & - \\
\hline $\begin{array}{c}31 \\
( \pm 1.0)\end{array}$ & & $0.92 *$ & - & - & - & $\begin{array}{c}8.9 \\
( \pm 1.3)\end{array}$ \\
\hline $\begin{array}{c}33 \\
( \pm 1.0)\end{array}$ & 1959 & 0.89 & - & - & $\begin{array}{l}-21.47 \\
( \pm 0.02)\end{array}$ & $\begin{array}{c}5.3 \\
( \pm 0.3)\end{array}$ \\
\hline $\begin{array}{c}35 \\
( \pm 1.0)\end{array}$ & & 0.92 & - & - & - & $\begin{array}{c}3.4 \\
( \pm 0.3)\end{array}$ \\
\hline $\begin{array}{c}37 \\
( \pm 1.0)\end{array}$ & & $0.95 *$ & - & - & $\begin{array}{c}-21.38 \\
( \pm 0.01)\end{array}$ & $\begin{array}{r}26.9 \\
( \pm 0.5)\end{array}$ \\
\hline $\begin{array}{c}39 \\
( \pm 1.0)\end{array}$ & 1957 & 0.97 & - & - & - & $\begin{array}{c}34.3 \\
( \pm 1.8)\end{array}$ \\
\hline $\begin{array}{c}41 \\
( \pm 1.0)\end{array}$ & & $0.98 *$ & - & - & $\begin{array}{l}-21.28 \\
( \pm 0.02)\end{array}$ & $\begin{array}{c}6.8 \\
( \pm 1.2)\end{array}$ \\
\hline $\begin{array}{c}43 \\
( \pm 1.0)\end{array}$ & & $0.99 *$ & $\begin{array}{l}-364 \\
( \pm 10)\end{array}$ & $\begin{array}{c}3640 \\
( \pm 130)\end{array}$ & $\begin{array}{c}-21.23 \\
( \pm 0.04)^{*}\end{array}$ & $\begin{array}{r}15.5 \\
( \pm 1.8)\end{array}$ \\
\hline $\begin{array}{c}45 \\
( \pm 1.0)\end{array}$ & & 1.00 & - & - & $\begin{array}{l}-21.19 \\
( \pm 0.02)\end{array}$ & $\begin{array}{c}9.2 \\
( \pm 1.6)\end{array}$ \\
\hline $\begin{array}{c}47 \\
( \pm 1.0)\end{array}$ & & 1.07 & - & - & - & - \\
\hline $\begin{array}{c}49 \\
( \pm 1.0)\end{array}$ & 1955 & - & - & - & & - \\
\hline $\begin{array}{c}51 \\
( \pm 1.0)\end{array}$ & & - & - & - & - & - \\
\hline $\begin{array}{c}53 \\
( \pm 1.0)\end{array}$ & & - & & - & - & - \\
\hline $\begin{array}{c}55 \\
( \pm 1.0)\end{array}$ & & & & - & - & - \\
\hline $\begin{array}{c}57 \\
( \pm 1.0)\end{array}$ & & & & - & $\begin{array}{l}-21.35 \\
( \pm 0.02)\end{array}$ & - \\
\hline $\begin{array}{c}59 \\
( \pm 1.0)\end{array}$ & & 1.20 & - & - & - & $\begin{array}{c}10.8 \\
( \pm 0.2)\end{array}$ \\
\hline $\begin{array}{c}61 \\
( \pm 1.0)\end{array}$ & & & - & - & $\begin{array}{l}-21.46 \\
( \pm 0.02)\end{array}$ & - \\
\hline $\begin{array}{c}63 \\
( \pm 1.0)\end{array}$ & & - & $\begin{array}{l}-334 \\
( \pm 7)\end{array}$ & $\begin{array}{c}3260 \\
( \pm 130)\end{array}$ & $\begin{array}{c}-21.46 \\
( \pm 0.02)^{*}\end{array}$ & - \\
\hline $\begin{array}{c}65 \\
( \pm 1.0)\end{array}$ & & 0.95 & - & - & $\begin{array}{l}-21.46 \\
( \pm 0.02)\end{array}$ & $\begin{array}{c}8.9 \\
( \pm 0.4)\end{array}$ \\
\hline $\begin{array}{c}67 \\
( \pm 1.0)\end{array}$ & & - & - & - & - & - \\
\hline $\begin{array}{c}69 \\
( \pm 1.0)\end{array}$ & & - & - & - & $\begin{array}{l}-21.40 \\
( \pm 0.04)\end{array}$ & - \\
\hline $\begin{array}{c}71 \\
( \pm 1.0)\end{array}$ & & $0.97 *$ & - & - & - & $\begin{array}{c}24.8 \\
( \pm 2.1)\end{array}$ \\
\hline $\begin{array}{c}73 \\
( \pm 1.0)\end{array}$ & & - & - & - & - & - \\
\hline
\end{tabular}




\section{ACCEPTED MANUSCRIPT}

\begin{tabular}{cccccc}
75 & - & - & - & -21.50 & - \\
$( \pm 1.0)$ & & & & $( \pm 0.02)$ & \\
77 & $0.98^{*}$ & - & - & - & 9 \\
$( \pm 1.0)$ & & & & & $( \pm 1.0)$ \\
79 & 0.99 & - & - & -21.87 & - \\
$( \pm 1.0)$ & & & & $( \pm 0.02)$ & \\
81 & - & - & - & - & - \\
$( \pm 1.0)$ & & & & & \\
83 & - & - & - & -22.00 & - \\
$( \pm 1.0)$ & - & - & - & - & - \\
85 & & & & & \\
$( \pm 1.0)$ & $0.99 *$ & -350 & 3460 & -21.96 & 22.8 \\
87 & & $( \pm 10)$ & $( \pm 130)$ & $( \pm 0.01)$ & $( \pm 1.3)$ \\
$( \pm 1.0)$ & & & & & \\
\hline
\end{tabular}




\section{Figure captions}

Figure 1. Sampling site on Mississippi River used for seasonal survey and yearly reoccupation. Core location in Gulf of Mexico: core 93P13 \#2 = 28 $55.5^{\prime} \mathrm{N}, 89^{\circ} 40.6^{\prime} \mathrm{W}$ in about $60 \mathrm{~m}$ water depth (Oktay et al., 2000), with new carbon isotopic results described here.

Figure 2. Downcore variations of $\Delta^{14} \mathrm{C}$ (a) and $\delta^{13} \mathrm{C}(\mathrm{b})$.

Figure 3. Percent organic carbon (OC) and total ${ }^{127}$ Iodine concentration (ppm) as a function of depth.

Figure 4. Total iodine concentrations as a function of $\% \mathrm{OC}$, demonstrating a trend line of increasing iodine with increasing organic carbon concentrations, with the outliers consisting of data points from the layers that were deposited episodically and that were inferred to contain peat-OC.

Figure 5. Linear relationship between ${ }^{14} \mathrm{C}$ age (years) and $\delta^{13} \mathrm{C}(\% \circ)$ for data points between 1950-1993. 


\section{ACCEPTED MANUSCRIPT}

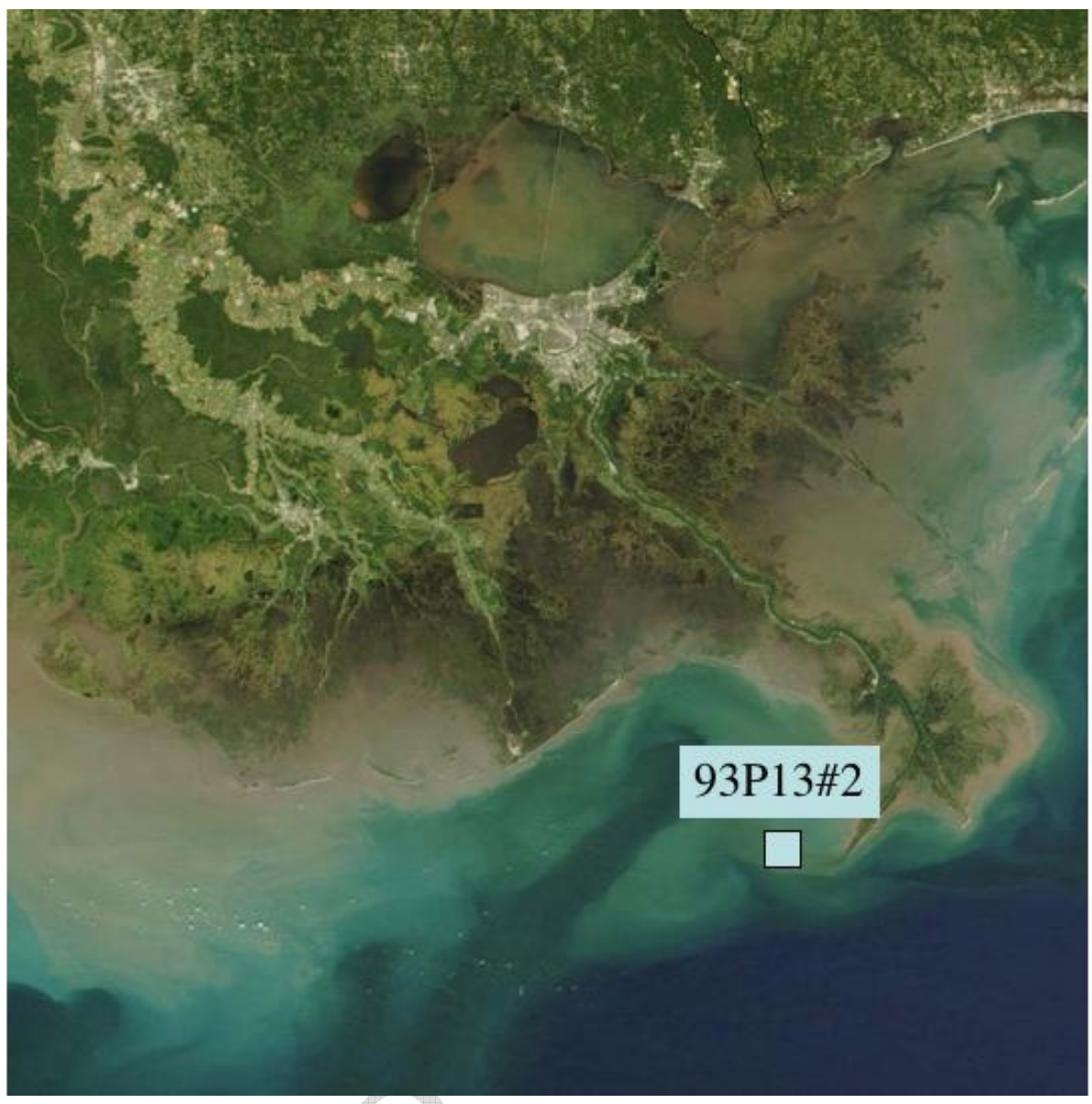

Fig. 1 


\section{ACCEPTED MANUSCRIPT}
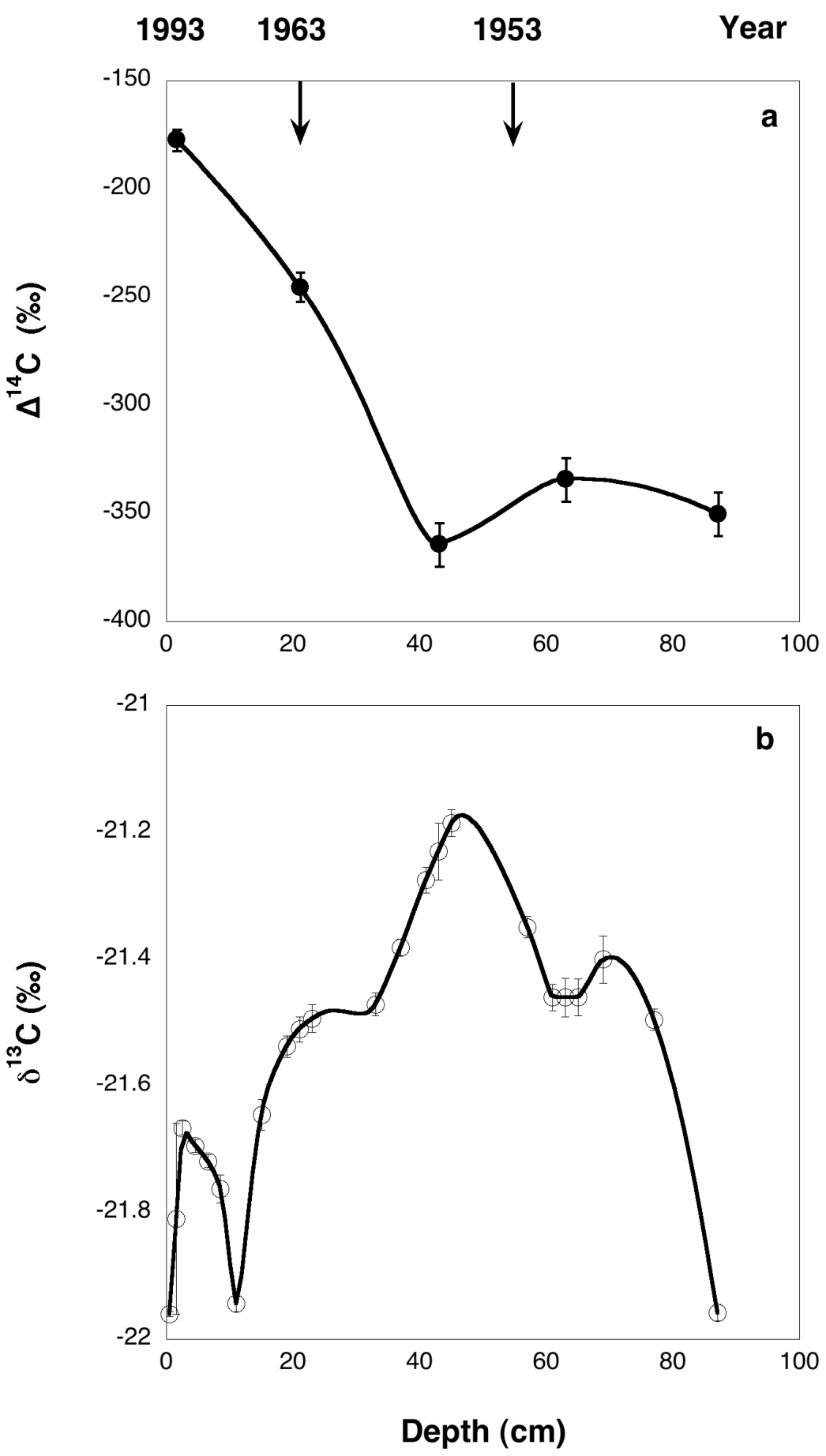

Fig. 2 


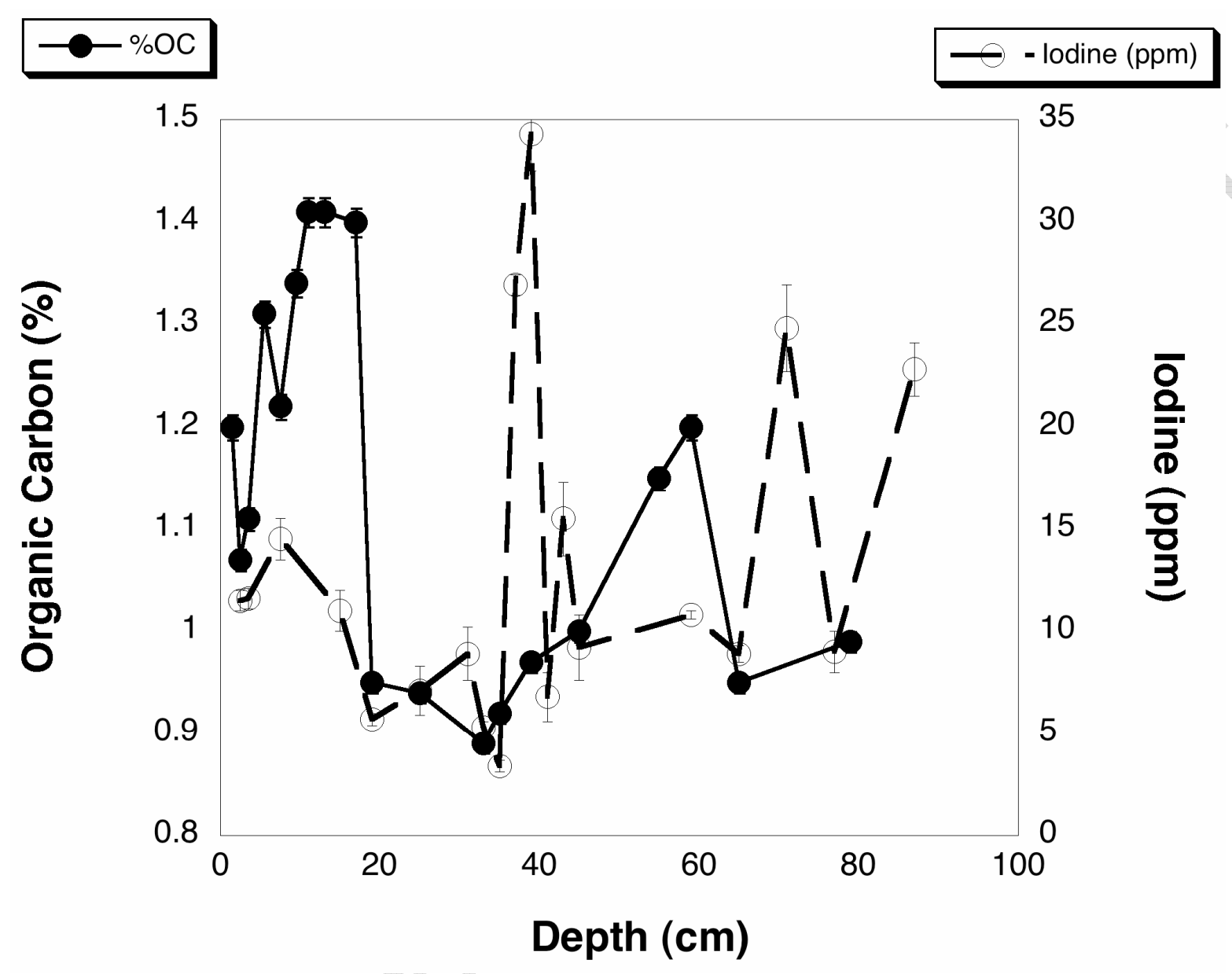

Fig. 3 


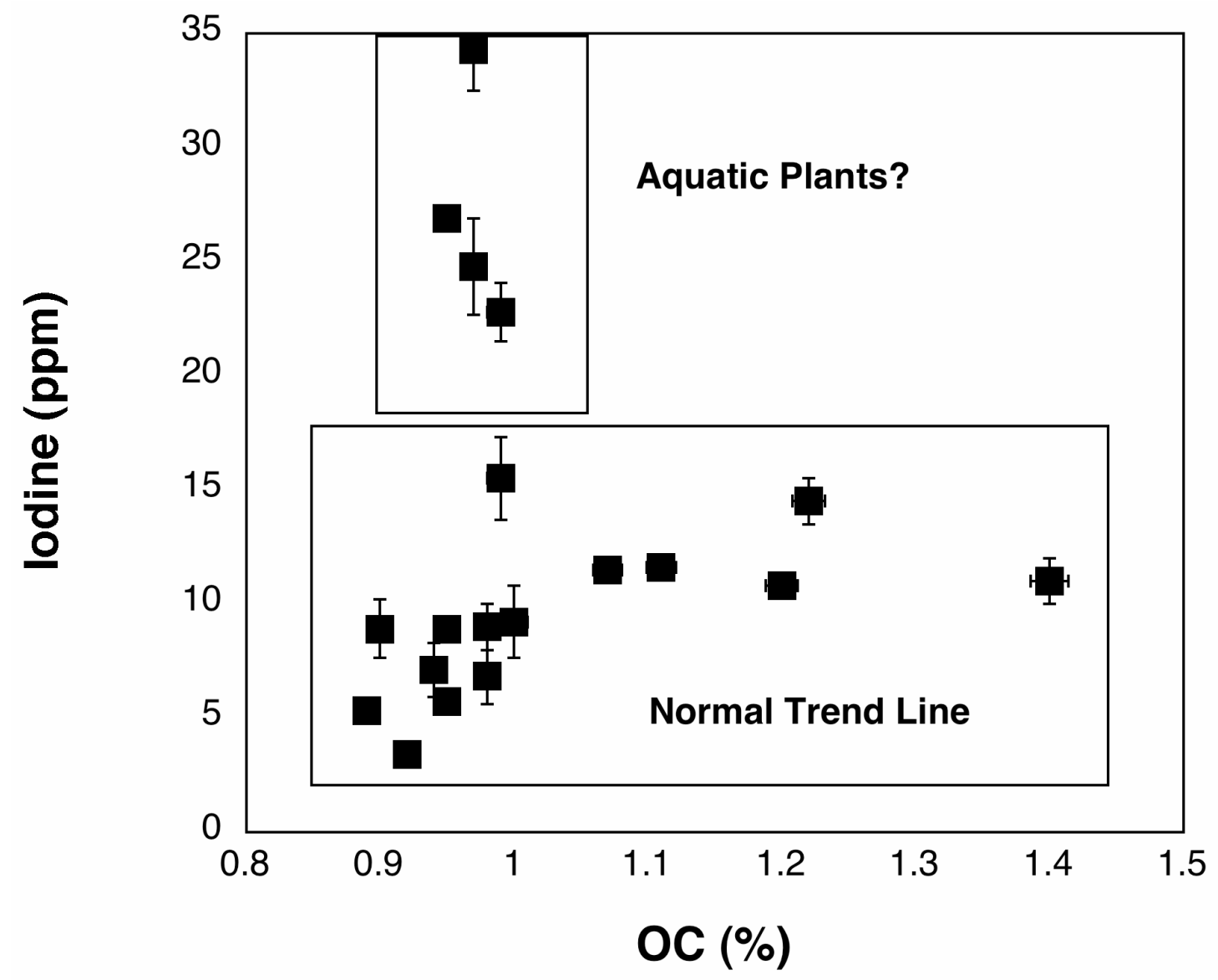

Fig. 4 


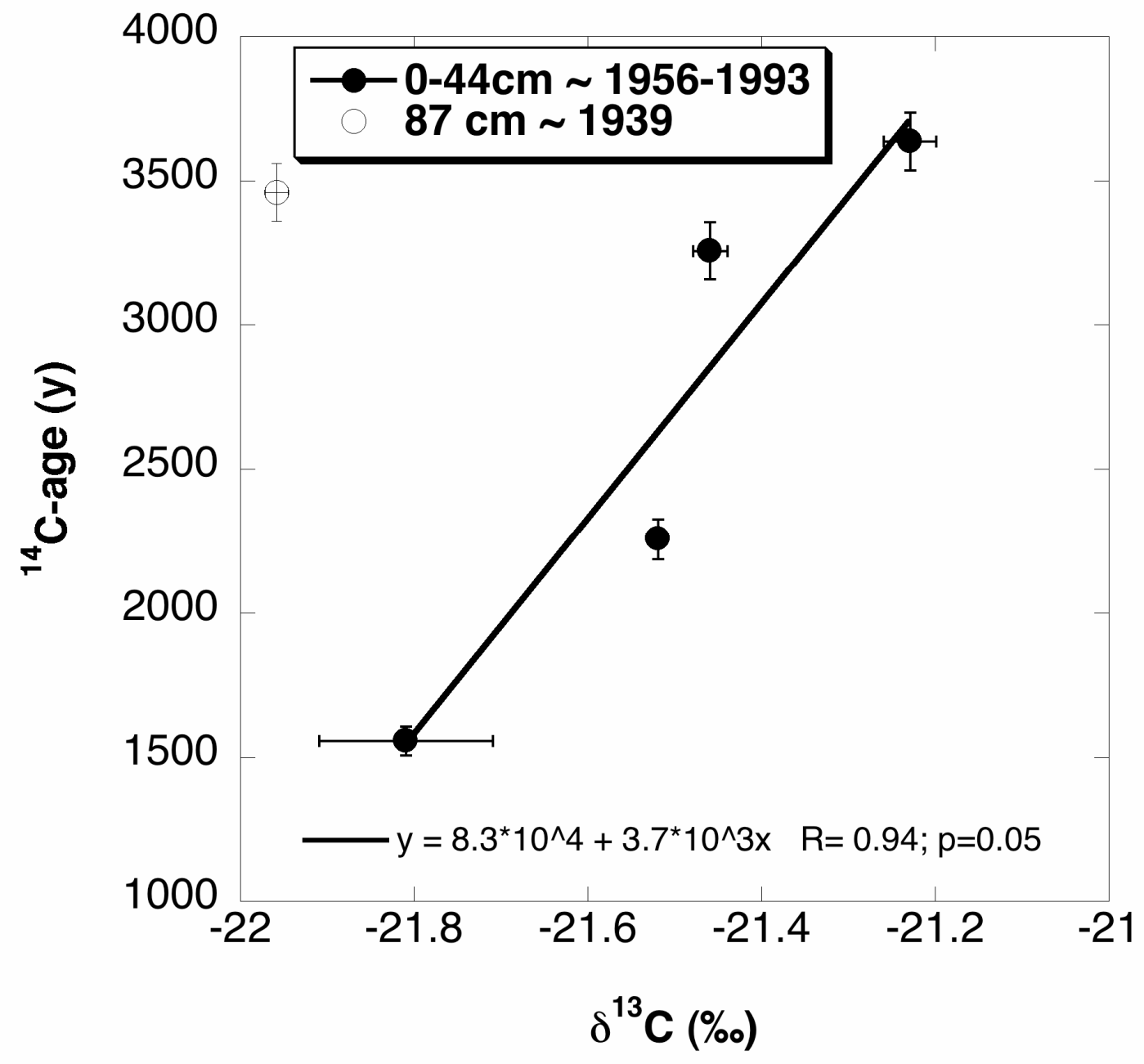

Fig. 5 